Article

\title{
Experimental and Numerical Study of Jet Controlled Compression Ignition on Combustion Phasing Control in Diesel Premixed Compression Ignition Systems
}

\author{
Qiang Zhang, Wuqiang Long, Jiangping Tian *, Yicong Wang and Xiangyu Meng \\ Institute of Internal Combustion Engine, Dalian University of Technology, Dalian 116024, China; \\ E-Mails: zq_0707@mail.dlut.edu.cn (Q.Z.); longwq@dlut.edu.cn (W.L.); \\ wangyicong@mail.dlut.edu.cn (Y.W.); mengxiangyu0114@mail.dlut.edu.cn (X.M.) \\ * Author to whom correspondence should be addressed; E-Mail: tianjp@dlut.edu.cn; \\ Tel./Fax: +86-411-8470-8246.
}

Received: 8 April 2014; in revised form: 27 May 2014 / Accepted: 8 July 2014 /

Published: 15 July 2014

\begin{abstract}
In order to directly control the premixed combustion phasing, a Jet Controlled Compression Ignition (JCCI) for diesel premixed compression ignition systems is investigated. Experiments were conducted on a single cylinder natural aspirated diesel engine without EGR at $3000 \mathrm{rpm}$. Numerical models were validated by load sweep experiments at fixed spark timing. Detailed combustion characteristics were analyzed based on the BMEP of 2.18 bar. The simulation results showed that the high temperature jets of reacting active radical species issued from the ignition chamber played an important role on the onset of combustion in the JCCI system. The combustion of diesel pre-mixtures was initiated rapidly by the combustion products issued from the ignition chamber. Moreover, the flame propagation was not obvious, similar to that in Pre-mixed Charge Compression Ignition (PCCI). Consequently, spark timing sweep experiments were conducted. The results showed a good linear relationship between spark timing in the ignition chamber and CA10 and CA50, which indicated the ability for direct combustion phasing control in diesel PCCI. The $\mathrm{NO}_{\mathrm{x}}$ and soot emissions gradually changed with the decrease of spark advance angle. The maximum reduction of $\mathrm{NO}_{\mathrm{x}}$ and soot were both over $90 \%$, and $\mathrm{HC}$ and $\mathrm{CO}$ emissions were increased.
\end{abstract}

Keywords: diesel combustion; jet controlled compression ignition; premixed combustion 


\section{Introduction}

Due to the higher thermal efficiency and greater reliability of direct injection diesel engines, they are extensively employed in stationary and portable engines. However, the trade-off between $\mathrm{NO}_{\mathrm{x}}$ and soot in the direct injection diesel engine needs to be overcome immediately due to the increasingly stringent emission legislation. In 1981, a hot premixed diesel combustion mode was proposed by Hu to overcome this relationship [1,2]. Subsequent research has been performed on this topic since then $[3,4]$. This combustion mode is usually called Pre-mixed Charge Compression Ignition (PCCI) or Homogeneous Charge Compression Ignition (HCCI) [5-8]. For diesel PCCI, the end of injection is usually earlier than ignition, therefore there is no direct relationship between fuel injection phasing and combustion phasing, unlike in mixing controlled combustion. Thus, the challenge was how to achieve active and direct control of combustion phasing.

The ignition process in PCCI is greatly affected by fuel properties, therefore research on combustion phasing control in PCCI was often around the control of fuel properties. Through in-cylinder blending using port fuel injection of gasoline and early direct injection of diesel, the peak cylinder pressure and peak heat release rate varied with the change of gasoline percentage, but the degree of linearity among them was reduced with an increase of gasoline percentage [9]. The study conducted by Johannes revealed that the diesel fuel stratification played an important role in the combustion timing control. With high stratification, two-stage combustion mode can be observed. Nevertheless, with improving mixing the combustion was retarded. If the diesel was completely mixed little effect of injection timing remained [10]. Although the chemical reactivity can be controlled through the blend of diesel and gasoline, higher heat transfer loss fraction would be seen for higher gasoline ratios. Additionally, the brake fuel conversion efficiency generally decreased as gasoline ratio increased [11]. Inlet heating was another way to control the combustion phasing. By changing the intake temperature, the crank angle at the start of heat release rate changed, but the variation in the range of intake temperatures was restricted by the load. In addition, the intake temperature cannot be changed instantaneously when load changes [12]. To expand the load range variable intake valve timing was often applied in PCCI. Using retarded intake valve closing timing, the load became wider for clean combustion while the combustion efficiency would be inferior. However, as the injection timing was retarded towards the Top Dead Centre (TDC), the effect of intake valve timing on the combustion phasing was weakened greatly [13]. Exhaust Gas Recirculation (EGR) was usually used to retard the combustion phasing [14]. The combustion phasing was delayed greatly with the increase in EGR rate [15]. The peak heat release rate and peak pressure were correspondingly reduced too. However, the impact of the EGR has two sides: a high EGR rate has a negative effect on the soot and performance.

In fact, all of the above measures were indirect approaches to govern the chemical-thermophysical properties of mixing, leading to a slow response to load variation and unavoidable advanced ignition at high load. Therefore, a compound combustion mode may be favored. It was revealed that by employing the Pulse Flame Jet (PFJ) system the onset of the ignition of homogeneous fuel-air mixture can be changed appropriately with the ignition timing of the PFJ igniter. Combustion characteristics from the images were similar to those of the auto-ignition case [16]. This showed that PFJ had the potential for actively controlling the start of homogenous charge combustion. Another similar research was done on the Hydrogen Assisted Jet Ignition (HAJI) system developed by Watson [17]. High efficiency and low 
$\mathrm{NO}_{\mathrm{x}}$ emissions as well as high combustion stability can be achieved in HAJI systems. Both the above systems draw upon the jet ignition concept introduced by Semenov in the late 1950s. This concept was further developed by Gussak. By employing this concept, the first jet ignition engine under the name of LAG was designed by Gussak [18,19]. The LAG system is equipped with a cam-actuated injector. The additional injector introduces a rich mixture into a pre-chamber. The flame jets issued from pre-chamber create multiple ignition sites leading to rapid combustion in the main chamber. A more feasible jet ignition system named Turbulent Jet Ignition (TJI) was developed by MAHLE Powertrain $[20,21]$. The fuel consumption was reduced by nearly $25 \%$ at part load. Ultra-low $\mathrm{NO}_{\mathrm{x}}$ emissions were achieved as well [22].

Although jet ignition systems had been developed extensively, most of them referred to gasoline engines or gas engines. Few were related to diesel engines, especially to diesel premixed combustion. Therefore, diesel premixed combustion employing a jet ignition concept called Jet Controlled Compression Ignition (JCCI) was investigated in this paper. The objective in this paper is to investigate the impact of the JCCI system on combustion phasing control of diesel premixed combustion.

\section{The JCCI System}

The principle of the JCCI system is that the near-critical ignition of premixed diesel mixture in main combustion chamber is initiated by jets of active radical species issued from an ignition chamber. Two key characteristics are involved in the JCCI system. First, a small ignition chamber comprised of a gas fuel injector and a spark plug is mounted on the cylinder head in a diesel engine. One or more small orifices are used to connect the ignition chamber and the main chamber. Furthermore, the compression ratio is reduced to avoid the auto-ignition of the premixed diesel fuel. After the rich gas fuel-air mixture in the ignition chamber is ignited by the spark plug, jets of combustion products pass through the connecting orifices. The near-critical premixed diesel fuel-air mixture is "ignited" by them. The multiple ignition sites shorten the flame propagation distance leading to rapid combustion in the main chamber, similar to that of HCCI. Therefore, the premixed combustion phasing can be controlled actively and directly by the spark discharge in the ignition chamber.

\section{Experimental and Numerical Setup}

A single cylinder, four-stroke, naturally aspirated, direct injection diesel engine with some modifications was used in the experiments. The original cylinder head was modified to use the JCCI system. The final profile of the JCCI system is illustrated in Figure 1. A spark plug and LPG injection pipe were assembled in the ignition chamber. The bottom of the ignition chamber was a dismountable nozzle with six orifices and a diameter of $1 \mathrm{~mm}$. The ignition chamber was mounted at the original position of the diesel injector while the diesel injector was mounted beside the ignition chamber. The compression ratio was reduced from 19 to 12 . The main specifications of the test engine are listed in Table 1. 
Figure 1. The profile of the JCCI system.

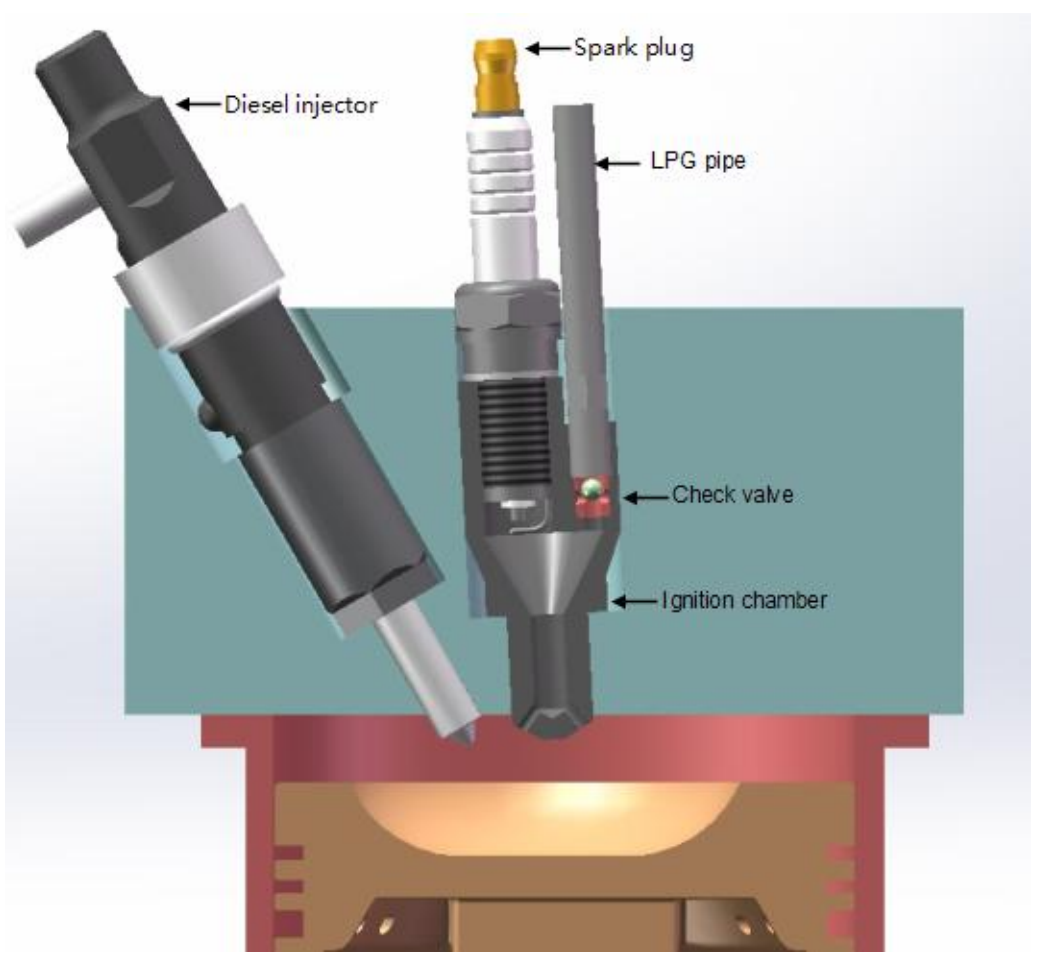

Table 1. Test engine.

\begin{tabular}{cc}
\hline Engine type & Specifications \\
\hline Bore $\times$ stoke & $86 \mathrm{~mm} \times 72 \mathrm{~mm}$ \\
Compression ratio & 12 \\
Ignition chamber volume & $1.7 \mathrm{~mL}$ \\
Rated speed for diesel engine & $3000 \mathrm{rpm}$ \\
Rated power for diesel engine & $5.68 \mathrm{~kW}$ \\
Intake valve opening (IVO) & $8.5^{\circ} \mathrm{BTDC}$ \\
Intake valve closing (IVC) & $44.5^{\circ} \mathrm{ABDC}$ \\
Exhaust valve opening (EVO) & $55.5^{\circ} \mathrm{BBDC}$ \\
Exhaust valve closing (EVC) & $8.5^{\circ} \mathrm{ATDC}$ \\
\hline
\end{tabular}

The schematic layout of the experimental setup is shown in Figure 2. The fuel used in the ignition chamber was Liquid Petroleum Gas (LPG) and a Port Fuel Injection (PFI) gaseous fuel injector was employed to control the injection of LPG. A ball check valve was placed in the ignition chamber to prevent backfire. The gas injector can be protected from the blast of high pressure and high temperature combustion mixture. The LPG injection pressure was fixed at $0.4 \mathrm{MPa}$ with a pressure regulator to ensure that LPG could be injected into ignition chamber during compression stoke. The LPG injection and ignition control programs were developed based on LabVIEW. A mechanical Pump-Pipe-Injector system was used to control the injection of diesel fuel in the main chamber. The injection timing of diesel fuel was set at $45^{\circ}$ Before Top Dead Centre (BTDC) to create a premixed air-fuel mixture. The spray angle of the nozzle was set to $90^{\circ}$ to avoid fuel impingement on the cylinder bore. 
Figure 2. Experimental setup.

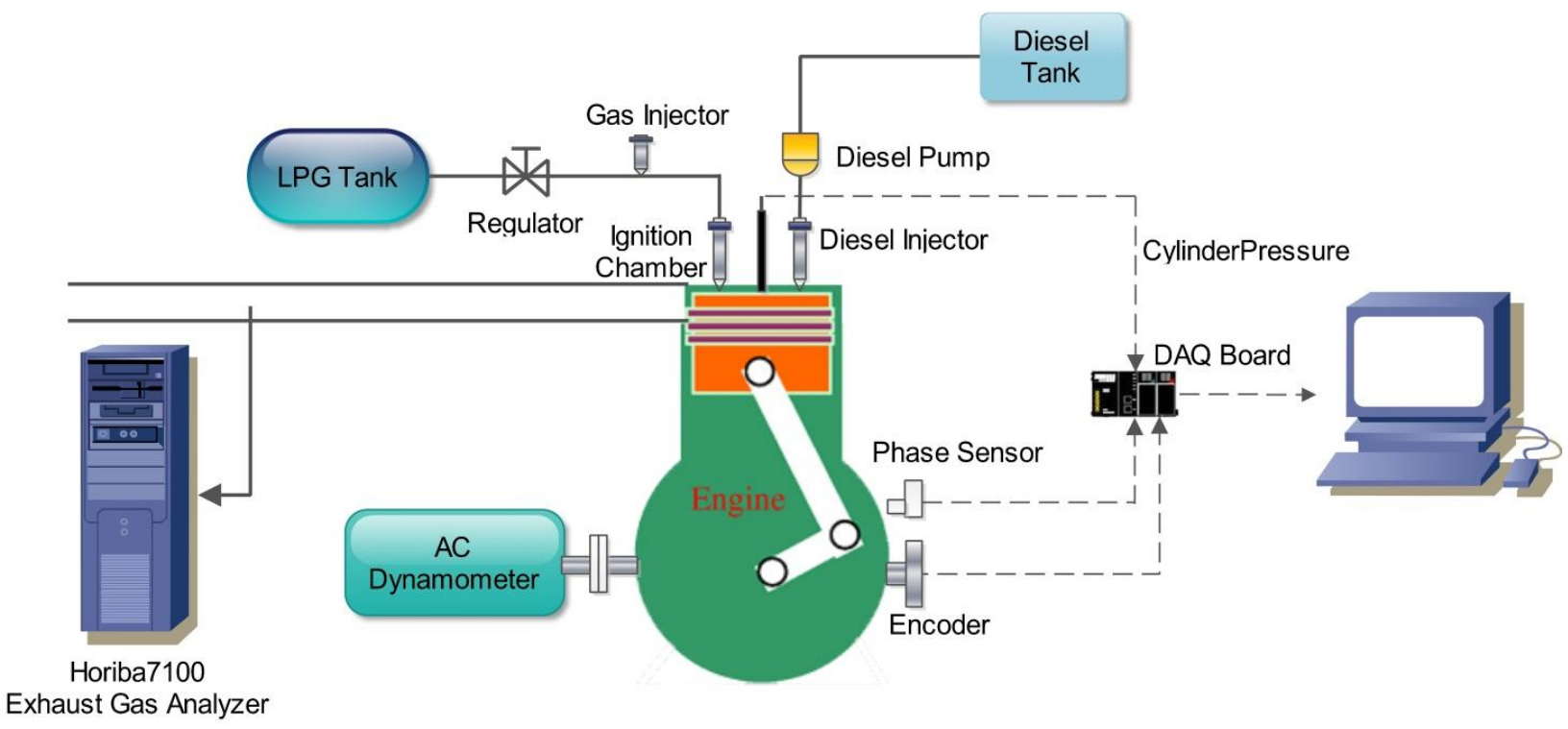

The regulated exhaust emissions of $\mathrm{CO}, \mathrm{CO}_{2}, \mathrm{O}_{2}$, THC and $\mathrm{NO}_{\mathrm{x}}$ were measured with a Horiba 7100 analyzer (Horiba Ltd., Kyoto, Japan). The smoke emission was measured with a FULI opacity smoke meter (FULI Analytical Instrument Co. Ltd., Guangzhou, China). The soot emissions were indicated by the measured smoke. All the emissions measured were sampled from the same point in the exhaust pipe. A piezo-electric pressure transducer, AVL GH14DK (AVL List Gmbh, Graz, Austria), coupled with a Lance0601 charge amplifier (Lance Technologies Inc., Qinhuangdao, China) was used to measure the cylinder pressure. An optical crankshaft encoder with $0.1^{\circ}$ Crank Angle (CA) resolution was used to measure the crank position. The pressure data from 100 consecutive cycles was recorded for each test condition using an NI CompactRIO high speed DAQ module (National Instruments, Austin, TX, USA). The cylinder pressure-crank angle data acquisition and combustion analysis programs were developed based on LabVIEW.

The experimental procedure was designed to achieve a general understanding of the impacts of JCCI system on the control of combustion phasing. First, the load sweep experiments were conducted at a fixed spark timing of $15^{\circ}$ BTDC.

The experimental pressure curves from the load sweep experiments were used to validate the numerical models using the CFD package AVL FIRE. The computational models and boundary conditions are listed in Table 2. Mesh cells near 120,000 at Top Dead Centre (TDC) were shown in Figure 3. The detailed combustion characteristics were analyzed according to the numerical results at the brake mean effective pressure (BMEP) of 2.18 bar. Consequently, spark timing sweep experiments were done to further analyze the effect of spark timing on combustion and emission characteristics. The operating conditions are listed in Table 3. 
Table 2. Computational models and boundary conditions.

\begin{tabular}{cc}
\hline Computational setup & Specifications \\
\hline Turbulent model & RNG $k-\varepsilon$ model [23] \\
Breakup model & KH-RT model [24] \\
Combustion model & ECFM-3Z model [25] \\
Swirl ratio & 2.5 \\
Intake pressure & $1.01 \mathrm{bar}$ \\
Intake temperature & $293 \pm 3 \mathrm{~K}$ \\
Cylinder liner temperature & $470 \mathrm{~K}$ \\
Cylinder head temperature & $550 \mathrm{~K}$ \\
Piston wall temperature & $550 \mathrm{~K}$ \\
Ignition chamber wall temperature & $580 \mathrm{~K}$ \\
\hline
\end{tabular}

Figure 3. Computational grid at TDC.

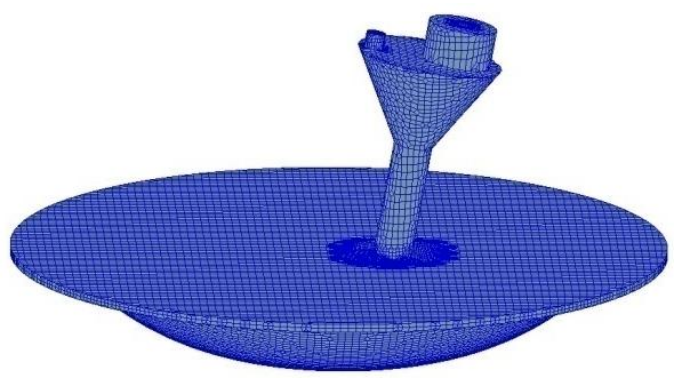

Table 3. Operating conditions.

\begin{tabular}{cc}
\hline Operating parameters & Specifications \\
\hline Speed & $3000 \mathrm{rpm}$ \\
BMEP & 1.09 bar to $3.27 \mathrm{bar}$ \\
Spark timing & $20^{\circ}$ to $5^{\circ} \mathrm{BTDC}$ \\
Diesel injection timing & $45^{\circ} \mathrm{BTDC}$ \\
LPG injection timing & $120^{\circ} \mathrm{BTDC}$ \\
\hline
\end{tabular}

\section{Results and Discussion}

\subsection{Numerical Analysis of Ignition Process in JCCI}

The load sweep experiments covered the range from $20 \%$ to $60 \%$ of the rated power. The $\max$ BMEP reached 3.27 bar. The apparent heat release rate (AHRR) was calculated from cylinder pressure using the First Law of Thermodynamics. Heat transfer was not considered in the calculation of AHRR. Both cylinder pressure and AHRR were employed to validate the computational models. The comparison results are shown in Figure 4. It can be observed that the predicted pressure curves matched the measurements well. The minimum deviation of peak pressure and position of peak pressure between simulation and measurement appeared at the BMEP of 2.18 bar. The predicted peak pressure was $3.55 \mathrm{MPa}$, that was almost same as the measured value $(3.56 \mathrm{MPa})$. The predicted position of peak pressure was $6.8^{\circ}$ ATDC that was the same as the measured data. The maximum deviation of peak pressure between predicted peak pressure and was below $0.04 \mathrm{MPa}$. The predicted AHRR is a little far 
from the experimental data. This can be expected from the increasing deviation between the predicted pressure and experimental pressure during expansion stroke as the increasing load, but the peak AHRR and the location of AHRR of predicted data were still close to those of the measurements.

Figure 4. Comparisons of in-cylinder pressure and AHRR between simulations and experiments.

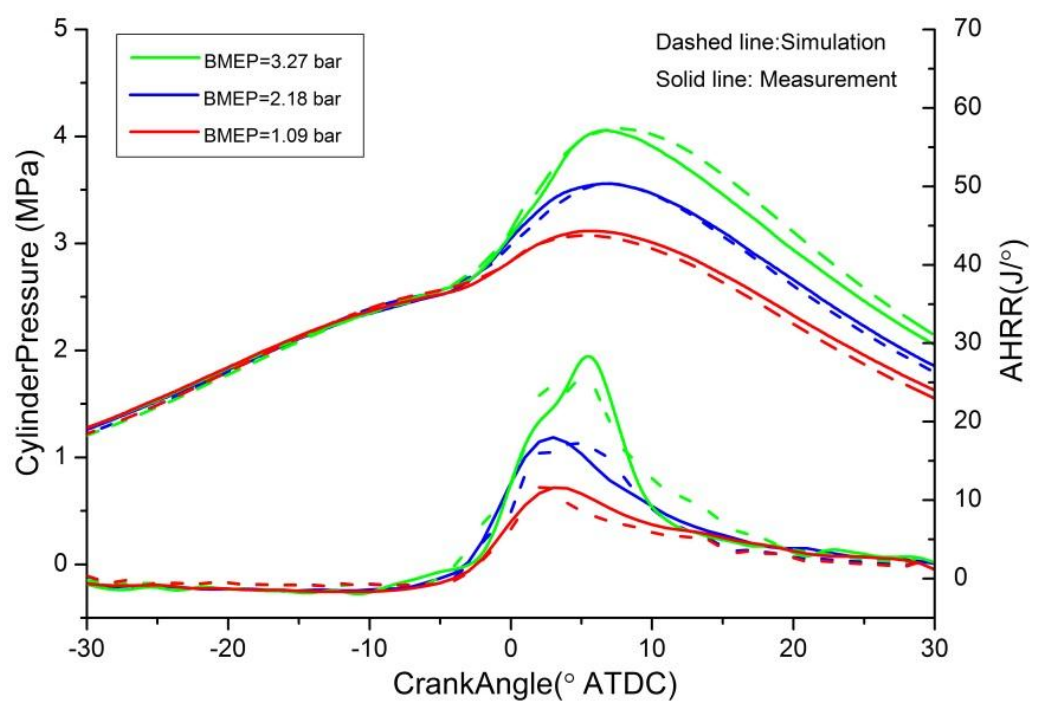

According to the comparison between the simulation and the measurement, the numerical results at BMEP of 2.18 bar were chosen to analyze the combustion characteristics in JCCI. The combustion characteristics after spark discharge including equivalence ratio, temperature, flame surface density and $\mathrm{OH}$ mass fraction are shown in Figure 5.

Figure 5. The distribution of equivalence, temperature, $\mathrm{OH}$ mass fraction and flame surface density at BMEP of 2.18 bar.

\section{$7^{\circ}$ BTDC}
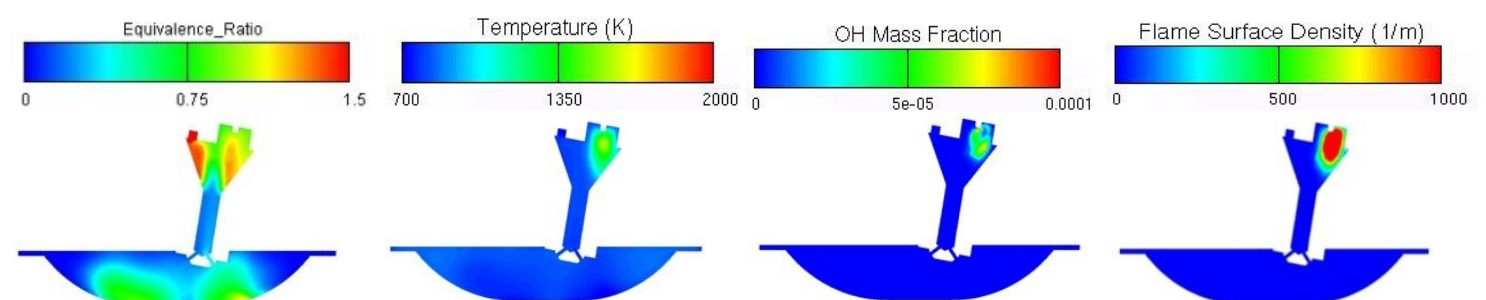

$2^{\circ}$ BTDC
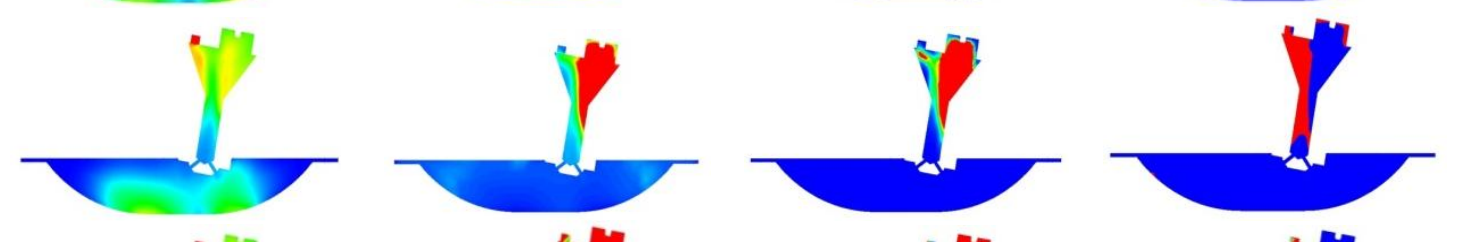

$3^{\circ}$ ATDC

\section{$13^{\circ}$ ATDC}
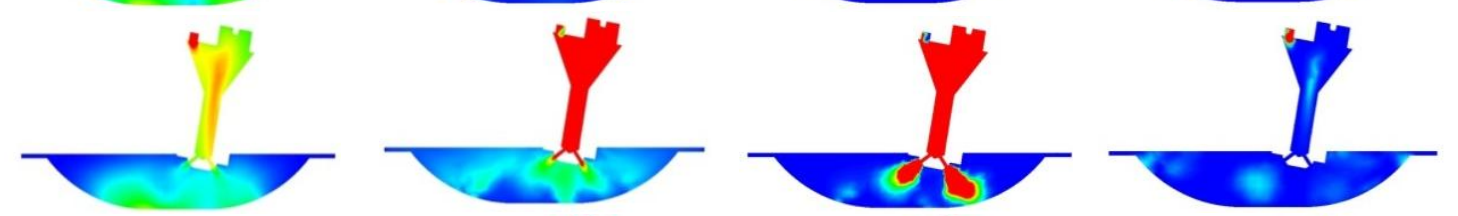

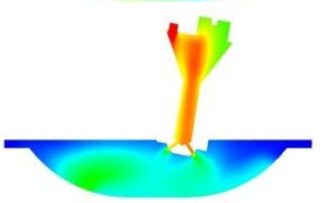

(a)

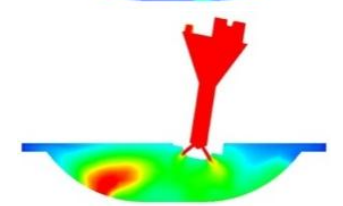

(b)

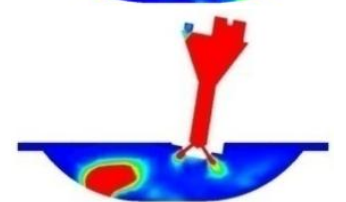

(c)

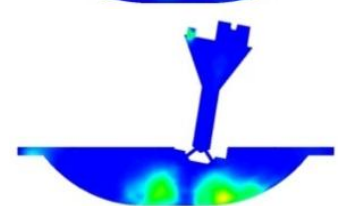

(d) 
It can be seen from Figure 5a that the distribution of diesel fuel in the main chamber was not very homogenous. An over-rich region cannot be completely avoided. The mixing time is not sufficient at a high speed, even though the injection timing is advanced greatly. Moreover, the low injection pressure using mechanical pump as well as the low injection backpressure cannot be avoided. Both these factors deteriorate the mixing process to some extent.

The evolution of the combustion process can be observed from Figure 5b. High temperature jets were introduced from the ignition chamber into the main chamber. Although the temperature of these jets decreased after passing through the six orifices connecting the ignition chamber and main chamber, it was enough to initiate the main combustion. Not only the ignition of fuel-air mixtures near the jets can be observed, but also the ignition of those beyond the jets can be seen. Except for the small areas with high temperature caused by the combustion of over-rich fuel-air mixture, most of the main combustion temperature was kept fairly low.

The distribution of $\mathrm{OH}$ mass fraction is shown in Figure 5c. After the discharge, large amounts of reacting active radicals were produced in the ignition chamber. As the high temperature jets injected into the main chamber, these active radicals were introduced as well. The evolution process of $\mathrm{OH}$ mass fraction was similar with that of temperature. As the introduction of active radicals, the main combustion was initiated quickly. The high $\mathrm{OH}$ mass fraction can be seen in the high temperature region as well.

In order to explore the flame propagation process, the distribution of flame surface density was presented in Figure 5d. The flame surface density is defined as flame surface area per unit volume [26]. Via this definition of term the process of flame propagation can be seen in Figure 5c. After the discharge of the spark plug, the flame appeared near the spark plug. It was propagated quickly and extensively in the ignition chamber, but most of the flames extinguished after they passing through the orifices. Only small areas with flame propagation can be seen in the region near the jets even though the main combustion was initiated. Due to the absent of flame propagation, the multiple auto-ignition of diesel fuel can be expected.

\subsection{Analysis of Spark Timing Sweep Experimental Results}

\subsubsection{Effects of Spark Timing on Combustion Characteristics}

Figure 6 shows a comparison of the cylinder pressure and AHRR at different spark timings for BMEP of 2.18 bar. As seen in the Figure 7, the fuel amounts injected of the spark timing sweep experiments varied little. As spark advance angle decreased, the peak cylinder pressure decreased proportionally. The Location of Peak Pressure (LPP) was retarded as well, except for that of $5^{\circ}$ BTDC. The increase in pressure was caused by compression and combustion. For a fixed speed and load, the pressure variation caused by compression barely changed in the tests. The variation in the peak pressure and LPP were mainly related to the combustion, which meant that the combustion was correspondingly delayed. This delay can also be seen for AHRR in the results. Although the peak AHRR only changed by a small amount, the location of the peak AHRR changed proportionally with the spark timing.

CA10 (crank angle where $10 \%$ of the total heat is released) and CA50 (crank angle where $50 \%$ of total heat release is released) are two important parameters that indicate combustion characteristics. The former is usually used to indicate the start of combustion and the latter is usually chosen to 
indicate the combustion phasing. As seen in Figure 8, CA10 and CA50 changed proportionally with the decrease of spark advance angle, presenting good linearity with spark timing. The fitted variation slope of CA50 and CA10 were 1.34 and 1.4, respectively, which meant that duration from CA10 to CA50 barely changed as well.

Figure 6. Comparison of cylinder pressure and apparent heat release rate at different spark timings.

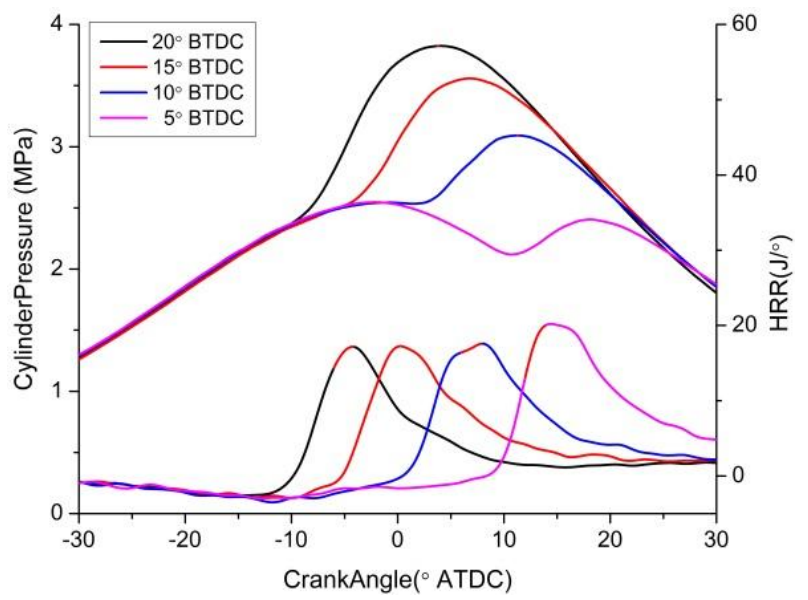

Figure 7. Comparison of brake thermal efficiency at different spark timings.

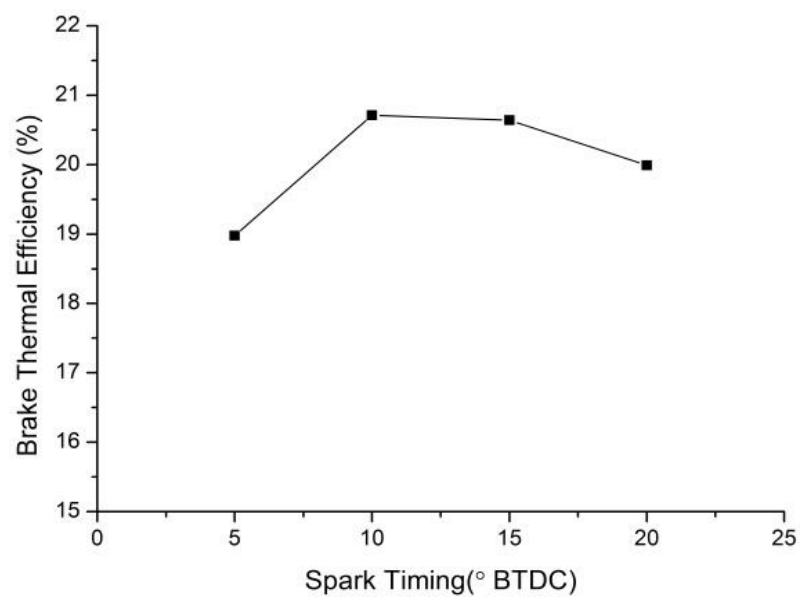

Figure 8. Variation of CA10 and CA50 with the spark timing.

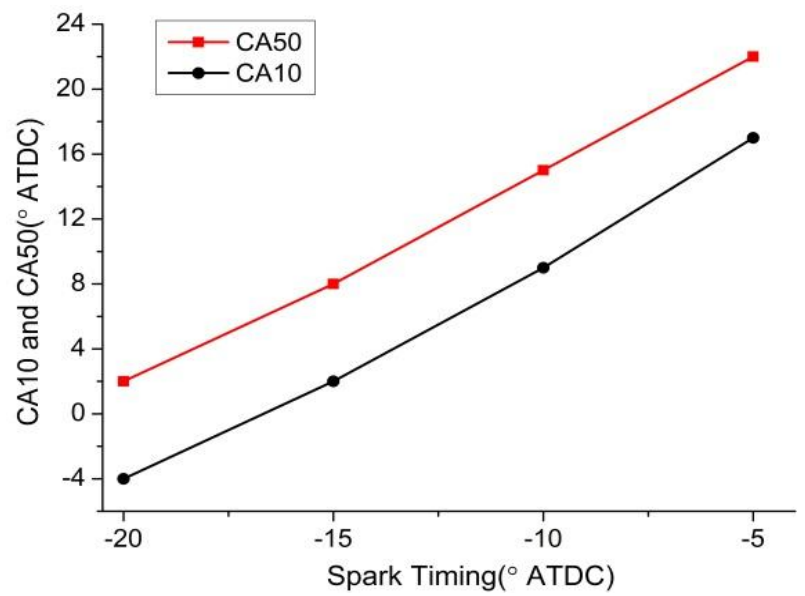


All above combustion characteristics were closely related with spark timing. First, with decrease of spark advance angle the onset of combustion were retarded gradually. Then most of combustion appeared over TDC and kept away from TDC gradually. As a result the peak pressure decreased gradually and the location of peak AHRR was retarded correspondingly.

\subsubsection{Effects of Spark Timing on Emissions}

Figure 9 shows the variation in $\mathrm{NO}_{\mathrm{x}}$ and soot emissions with spark timing for the BMEP of 2.18 bar. It can be clearly observed that $\mathrm{NO}_{\mathrm{x}}$ were greatly reduced compared with the original diesel engine, and the maximum reduction was greater than $95 \%$. The $\mathrm{NO}_{\mathrm{x}}$ emissions were mainly affected by the combustion temperature and local equivalence ratio. In contrast, the end of the diesel fuel injection was before the ignition. Thus, the mixture homogeneity was improved to some extent compared with the original diesel engine. Hence, the level of the local mixture heterogeneity was decreased. Then, the combustion temperature correspondingly decreased. The compression ratio of the JCCI engine was reduced from 19 to 12 . Therefore, the compression temperature of the in-cylinder gas before the start of combustion decreased greatly. Consequently, the combustion temperature was reduced accordingly. Both the above factors contributed to the significant reduction in the $\mathrm{NO}_{\mathrm{x}}$ emissions. In addition, an obvious linear relationship between $\mathrm{NO}_{\mathrm{x}}$ emission and the spark timing of ignition chamber can be seen in Figure 9. A steeper slope in the $\mathrm{NO}_{\mathrm{x}}$ variation was found when the spark timing was advanced from $15^{\circ}$ BTDC to $20^{\circ}$ BTDC. For one thing, the main combustion was advanced with an advance of the spark timing. Then, the combustion temperature increased with an advance of the combustion. For another thing, the diesel mixing time decreased with an advance in the spark timing with fixed fuel supply timing. Therefore, the local mixture homogeneity was likely to decrease and therefore, $\mathrm{NO}_{\mathrm{x}}$ increased proportionally with increasing spark advance angle.

Figure 9. $\mathrm{NO}_{\mathrm{x}}$ and soot emissions at different spark timings.

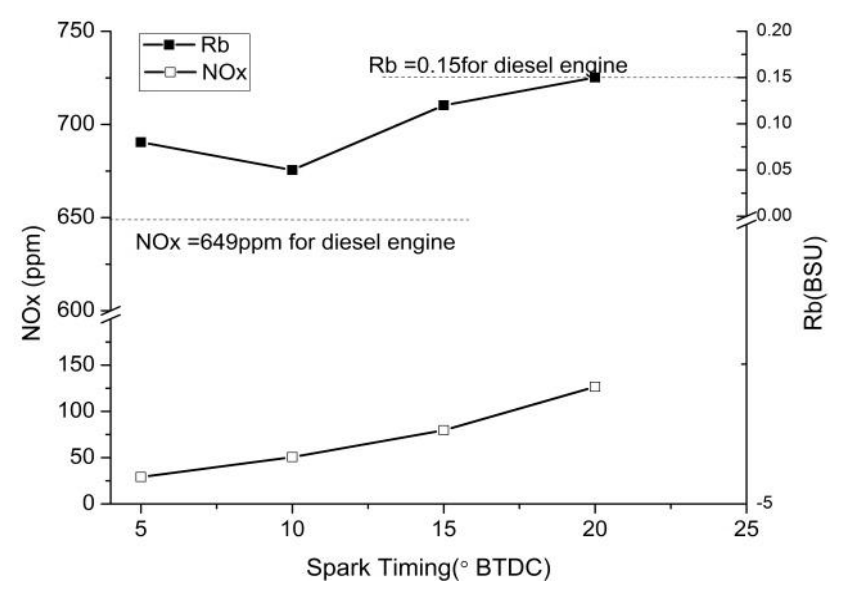

It can also be observed that the soot emissions were reduced proportionally with decreasing spark advance angle showing a similar trend as the $\mathrm{NO}_{\mathrm{x}}$ emissions. The maximum reduction in soot emissions, compared with the original diesel engine, was greater than $90 \%$ as well, and can be attributed to an improvement of the mixture homogeneity. As the spark advance angle decreased, there was mixing time for the fuel-air mixture. However, at the spark timing of $20^{\circ}$ BTDC, the soot achieved a level comparable with the original engine. 
Figure 10 shows the variation in $\mathrm{HC}$ and $\mathrm{CO}$ emissions with spark timing for the BMEP of 2.18 bar. Compared with the original diesel engine, they were much higher. This can be attributed to a decrease of the combustion temperature and the deteriorated atomization caused by the advanced injection timing. Moreover, both emissions showed similar trends. First, they decreased with increasing spark advance angle, then, a slight increase can be observed at a spark timing of $20^{\circ}$ BTDC.

Figure 10. $\mathrm{HC}$ and $\mathrm{CO}$ emissions at different spark timings.

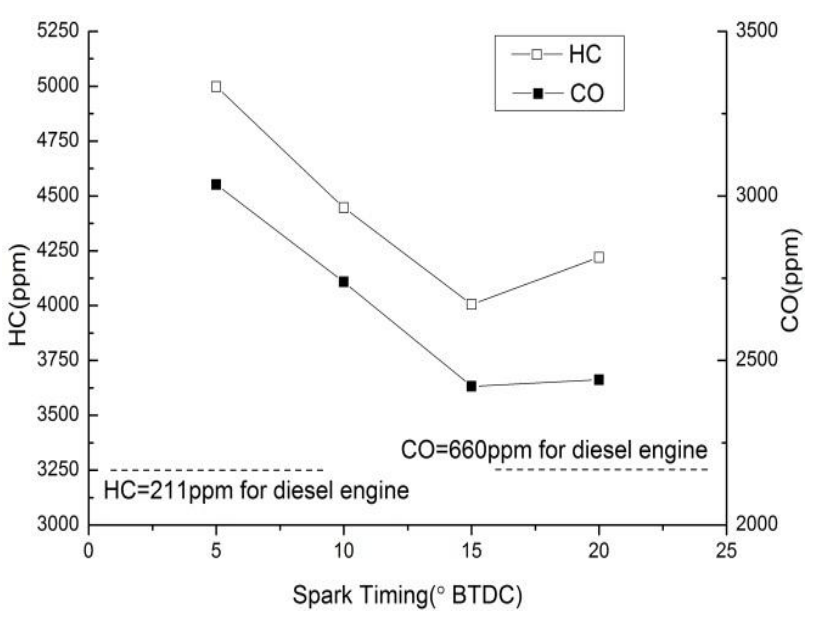

As mentioned before, increasing combustion temperature can be expected as the spark advance angle increases, therefore, the oxidation of $\mathrm{CO}$ and $\mathrm{HC}$ would be accelerated. However, as seen from Figure 7 the thermal efficiency of $20^{\circ}$ BTDC was a little lower than $15^{\circ}$ BTDC, therefore, the slight increase in $\mathrm{HC}$ and $\mathrm{CO}$ would be expected as well.

\section{Conclusions}

In the present work, the effect of the JCCI system on the combustion characteristics and emissions has been evaluated in terms of combustion phasing control for diesel premixed combustion. Both experimental and numerical results have been presented on a single cylinder natural aspirated diesel engine without EGR. The main combustion in the JCCI system was initiated by high temperature jets of reacting active radicals. The flame propagation process was not obvious, except for the area near the jets. The combustion process in the main chamber was similar with that in PCCI. Additionally, the equivalence rate was not uniform as well, due to the low injection pressure using a mechanical pump.

The effect of spark timing on the combustion characteristics revealed that combustion phasing can be controlled by using JCCI. Therefore, the control of pressure rise rate at high load in JCCI would be expected using the spark timing. Moreover, the spark timing is an effect way to optimize the emissions and thermal efficiency. However, the control window of spark timing was not very wide in terms of emissions and efficiency. High HC and low efficiency would both suffered be for a too advanced spark timing or too delayed spark timing.

\section{Acknowledgments}

This work was supported by the National Natural Science Foundation of China [No.51379034]; and High Technology Ship Program by the Ministry of Industry and Information Technology of China. 


\section{Author Contributions}

Wuqiang Long and Qiang Zhang conceived the idea of JCCI. Qiang Zhang and Jiangping Tian conducted the experiment and analyzed the data. Yicong Wang and Qiang Zhang modeled and analyzed the combustion process of JCCI. Xiangyu Meng provided the essential help to the simulation.

\section{Conflicts of Interest}

The authors declare no conflict of interest.

\section{References}

1. Hu, G. Prospect on diesel combustion research. J. Dalian Inst. Technol. 1982, 4, 71-80.

2. Hu, G. New Strategy on Diesel Combustion Development; SAE Technical Paper 900442; SAE International: Warrendale, PA, USA, 1 February 1990; doi:10.4271/900442.

3. Long, W.; Ohtsuka, H.; Obokata, T. Characterization of conical spray flow for diesel engine by means of laser doppler methods: PDA measurement of droplet size distribution. JSME Int. J. Series B Fluids Therm. Eng. 1996, 39, 554-561.

4. Leng, X.; Feng, L.; Tian, J.; Du, B.; Long, W.; Tian, H. A Study of the mixture formation process for a third-generation conical spray applied in HCCI diesel combustion. Fuel 2010, 89, 392-398.

5. Dumitrescu, C.E.; Neill, W.S.; Guo, H.; Hosseini, V.; Chippior, W.L. Fuel property effects on PCCI combustion in a heavy-duty diesel engine. Am. Soc. Mech. Eng. 2012, 134, 52801-52808.

6. Stanglmaier, R.H.; Roberts, C.E. Homogeneous Charge Compression Ignition (HCCI): Benefits, compromises, and future engine applications. Prog. Technol. 2003, 100, 477-484.

7. Luszcz, P.; Xu, H.; Wyzsnski, M.; Ma, X.; Stevens, R.; Tsolakis, A. Imaging studies of in-cylinder HCCI combustion. Front. Energy 2011, 5, 313-321.

8. Kuboyama, T.; Moriyoshi, Y.; Hatamura, K.; Suzuki, M.; Takanashi, J.; Yamada, T.; Gotoh, S. Effect of fuel and thermal stratifications on the operational range of an HCCI gasoline engine using the blow-down super charge system. SAE Int. J. Engines 2010, 3, 666-680.

9. Kokjohn, S.; Hanson, R.; Splitter, D.A.; Reitz, R.D. Experiments and modeling of dual-fuel HCCI and PCCI combustion using in-cylinder fuel blending. SAE Int. J. Engines 2009, 2, 24-39.

10. Benajes, J.; Novella, R.; Garcia, A.; Domenech, V.; Durrett, R. An investigation on mixing and auto-ignition using diesel and gasoline in a direct-injection compression-ignition engine operating in PCCI combustion conditions. SAE Int. J. Engines 2011, 4, 2590-2602.

11. Eichmeier, J.; Wagner, U.; Spicher, U. Controlling gasoline low temperature combustion by diesel micro pilot injection. J. Eng. Gas Turbines Power 2012, 134, 072802.

12. Flowers, D.; Aceves, S.M.; Martinez-Frias, J.; Smith, J.R.; Au, M.; Girard, J.; Dibble, R. Operation of a Four-Cylinder 1.9L Propane Fueled Homogeneous Charge Compression Ignition Engine: Basic Operating Characteristics and Cylinder-to-Cylinder Effects; SAE Technical Paper 2001-01-1895; SAE International: Warrendale, PA, USA, 7 May 2001; doi:10.4271/2001-01-1895.

13. Jia, M.; Xie, M.; Wang, T.; Peng, Z. The effect of injection timing and intake valve close timing on performance and emissions of diesel PCCI engine with a full engine cycle CFD simulation. Appl. Energy 2011, 88, 2967-2975. 
14. Kim, D.S.; Lee, C.S. Improved emission characteristics of HCCI engine by various premixed fuels and cooled EGR. Fuel 2006, 85, 695-704.

15. Park, Y.; Bae, C. Influence of EGR and Pilot Injection on PCCI Combustion in a Single-Cylinder Diesel Engine; SAE Technical Paper 2011-01-1823; SAE International: Warrendale, PA, USA, 30 August 2011; doi:10.4271/2011-01-1823.

16. Murase, E.; Hanada, K. Control of the Start of HCCI Combustion by pulsed flame jet; SAE Technical Paper 2002-01-2867; SAE International: Warrendale, PA, USA, 21 October 2002; doi:10.4271/2002-01-2867.

17. Kyaw, Z.H.; Watson, H.C. Hydrogen assisted jet ignition for near elimination of $\mathrm{NO}_{\mathrm{x}}$ and cyclic variability in the S.I. Engine. Symp. Int. Combust. 1992, 24, 1449-1455.

18. Gussak, L.A.; Michael, C.T.; Donald, C.S. High Chemical Activity of Incomplete Combustion Products and a Method of Prechamber Torch Ignition for Avalanche Activation of Combustion in Internal Combustion Engines; SAE Technical Paper 750890; SAE International: Warrendale, PA, USA, 1 February 1975; doi:10.4271/750890.

19. Gussak, L.A.; Karpov, V.P.; Tikhonov, Y.V. The Application of Lag-Process in Prechamber Engines; SAE Technical Paper 790692; SAE International: Warrendale, PA, USA, 1 February 1979; doi:10.4271/790692

20. Attard, W.P.; Neil, F.; Patrick, P.; Toulson, E. A turbulent jet ignition pre-chamber combustion system for large fuel economy improvements in a modern vehicle powertrain. SAE Int. J. Engines 2010, 3, 20-37.

21. Attard, W.P.; Michael, B.; Patrick, P.; Blaxill, H. A New Combustion System Achieving High Drive Cycle Fuel Economy Improvements in a Modern Vehicle Powertrain; SAE Technical Paper 2011-01-0664; SAE International: Warrendale, PA, USA, 12 April 2011; doi:10.4271/2011-01-0664.

22. Attard, W.; Blaxill, H. A Lean Burn Gasoline Fueled Pre-Chamber Jet Ignition Combustion System Achieving High Efficiency and Low NO $O_{x}$ at Part Load; SAE Technical Paper 2012-01-1146; SAE International: Warrendale, PA, USA, 16 April 2012; doi:10.4271/2012-01-1146.

23. Hanjalić, K.; Popovac, M.; Hadžiabdić, M. A robust near-wall elliptic-relaxation eddy-viscosity turbulence model for CFD. Int. J. Heat Fluid Flow 2004, 25, 1047-1051.

24. Huh, K.Y.; Gosman, A.D. A phenomenological model of diesel spray atomization. In Proceedings of the International Conference on Multiphase Flows, Tsukuba, Japan, 24-27 September 1991.

25. Colin, O.; Benkenida, A. The 3-Zones extended coherent flame model (Ecfm3z) for computing premixed/diffusion combustion. Oil Gas Sci. Technol. 2004, 59, 593-609.

26. Renou, B.; Mura, A.; Samson, E.; Boukhalfa, A. Characterization of the local flame structure and the flame surface density for freely propagating premixed flames at various Lewis numbers. Combust. Sci. Technol. 2010, 174, 143-179.

(C) 2014 by the authors; licensee MDPI, Basel, Switzerland. This article is an open access article distributed under the terms and conditions of the Creative Commons Attribution license (http://creativecommons.org/licenses/by/3.0/). 